\title{
AM5 $5.07(74.71)$
}

.S53 Shapiro, L. H.

1945 Man, Mankind and museums

** 1945 
LIBRARY OF THE

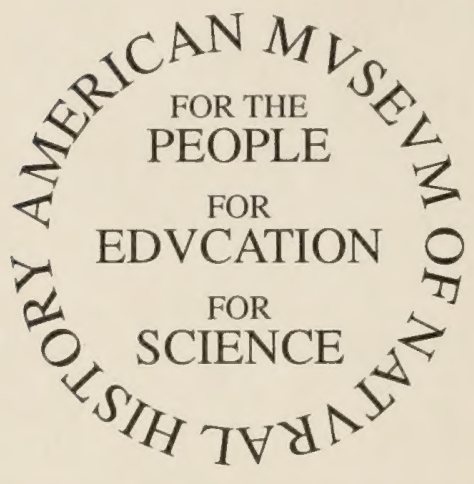




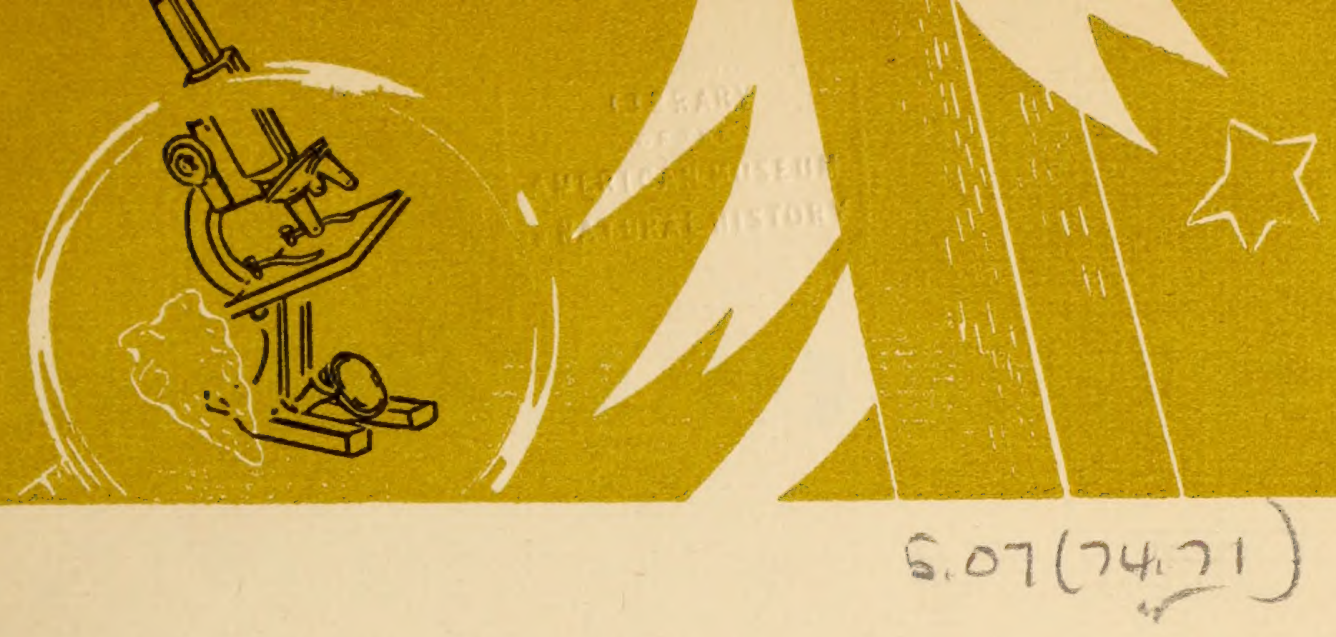

\section{MAN, MANKIND AND MUSEUMIS}

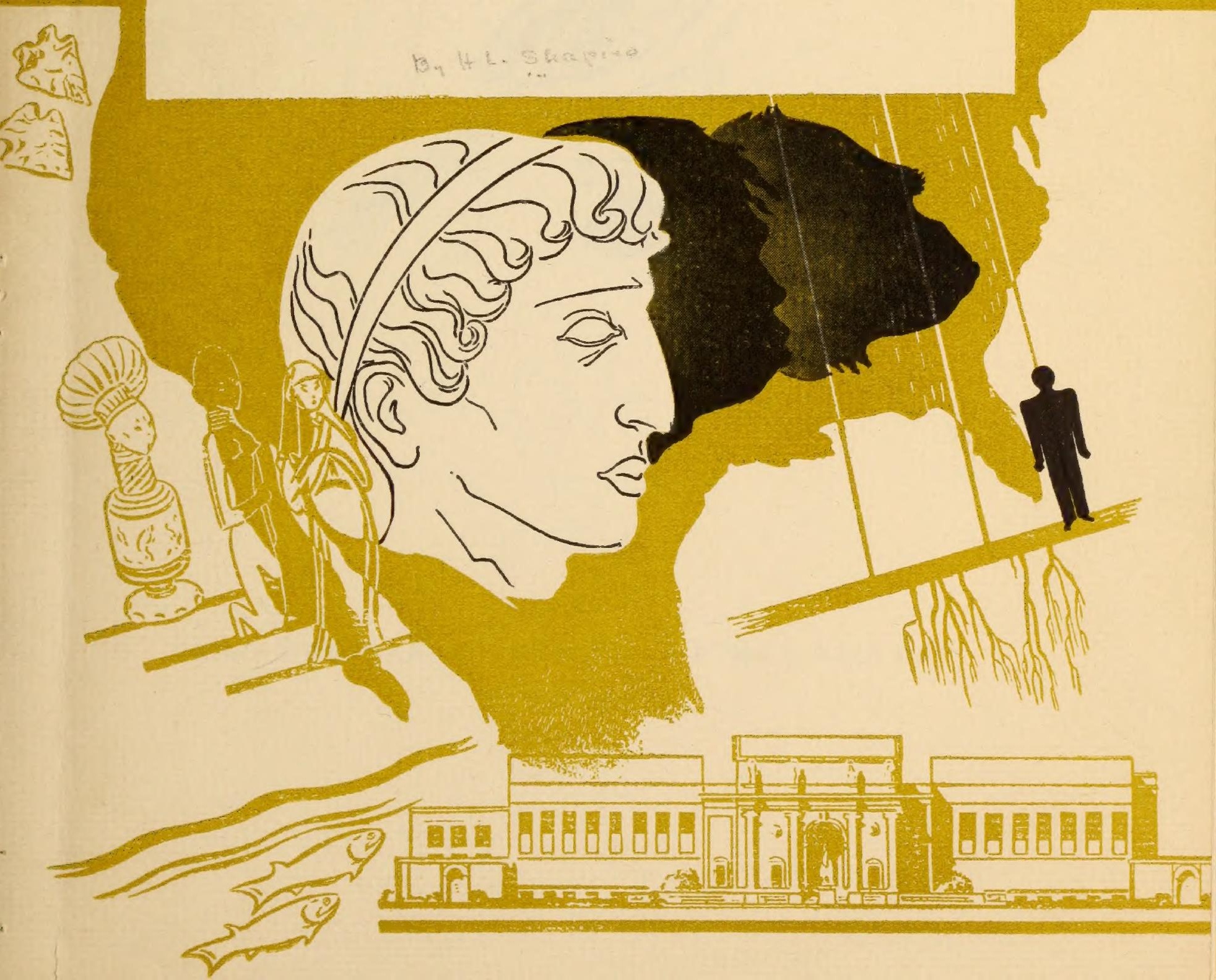





\section{MAN, MANKIND AND MUSEUMS}

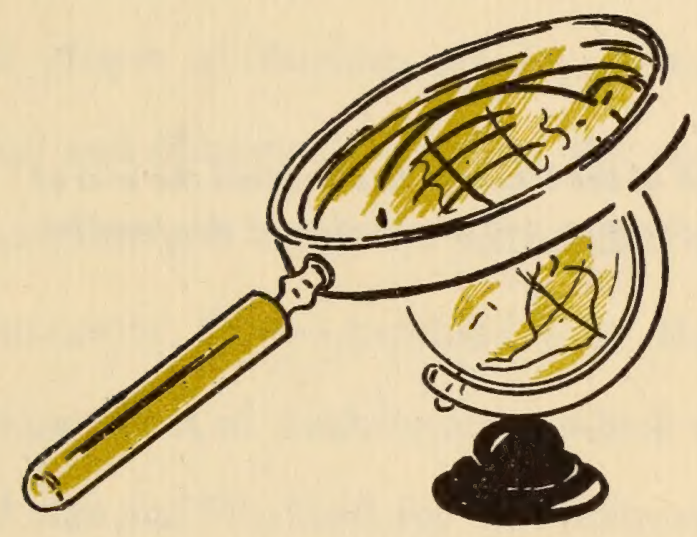

$M \quad M X L V$

THE AMERICAN MUSEUM OF NATURAL HISTORY N E W Y O R K 
A friend of the Museum has donated the cost of the preparation and production of this booklet.

$45 \cdot 162023-$ Now 8

Illustrated by Paula A. Hutchison 


\section{F OREW OR D}

It is the custom of the Museum Contributors Program Committee occasionally to distribute a booklet to friends of the Museum emphasizing particular phases of Museum activity. The accompanying story "Man, Mankind and Museums" contrasts the old museum conception with the modern one and shows the importance of the Museum in the life of the community. We are indebted to Dr. Harry L. Shapiro, Chairman of the Department of Anthropology, which might well be called the Department of Man and Mankind, for this interesting exposition. It will have served its purpose well if present contributors, as well as new contributors that we hope to interest, gain a better insight into the ideals of this great institution.

The peoples of the world who stand for freedom based on human enlightenment are battling those evil forces which have sought to subjugate both the bodies and minds of mankind. But although military victory is certain, the battle of ideas will continue. Since Man is a product of 
Nature-living, moving and having his being in a world of Nature-he must acquaint himself with the Laws of Nature, upon which his life depends. True progress for mankind depends upon Man's understanding of Nature:- the more thorough and universal the understanding, the greater progress Man will make towards the perfection of life.

Natural History Museums, truly universities of Nature, will play an ever more important part in this process of human enlightenment. As this museum function is more generally recognized, museums will obtain the support necessary for their development.

$$
\text { a Pry crom }
$$




\section{MAN, MANKIND AND MUSEUMS}

Words have a way of changing their meaning as custom and need demand. Shakespeare used to say "let" when he meant prevent and "prevent" when he meant anticipate or come before. Institutions are not unlike words. They stand for different things at different times. They, too, evolve and change to fit circumstances and the needs of the community they serve. Let us consider, for a moment, what has happened to the idea that lies behind the word "museum." Originally, it meant a temple devoted to the Muses; those nine Greek divinities who presided over the arts of diverse forms of poetry, history, music, dance

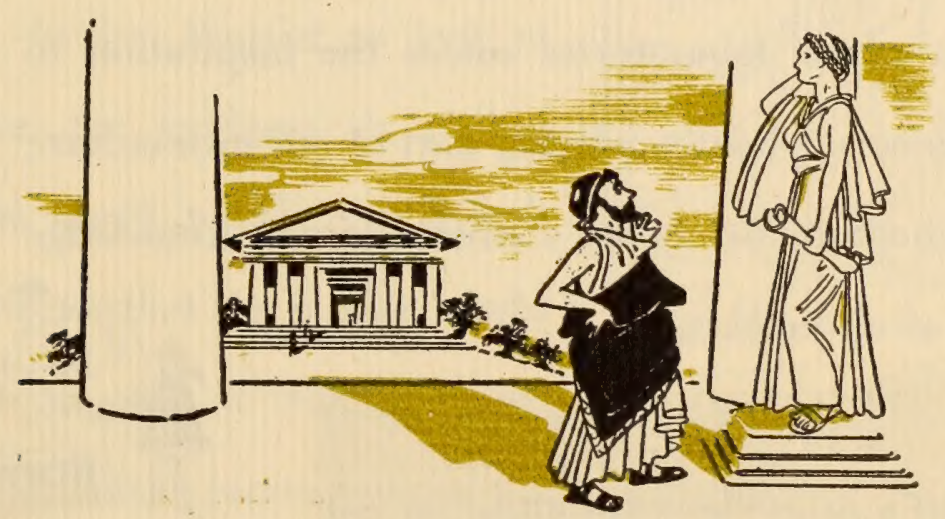


and astronomy. Later, when the Muses faded into the realm of classical allusion and poetic personification, the museum itself survived to fill the need of a repository for objects of art and science. To many, unfortunately, this still remains the concept of a museum, but actually the museum has continued to develop and change its meaning in harmony with our social evolution until at present it would be archaic to restrict a museum by definition merely to its curatorial function. In its modern and fullest sense, a museum is far more than a repository, important as that is in guarding for posterity the achievements of our past. It is an educational establishment where the very objects, held in trust, may be used to inform and enlighten the public in a manner impossible for schools and universities. It is a research institution from whose laboratories comes the inspiration to make the objects it houses a living part of our own culture and from whose studies issues a stream of new knowledge for benefit of all mankind.

\section{This development and enrichment of} the museum's important function in our

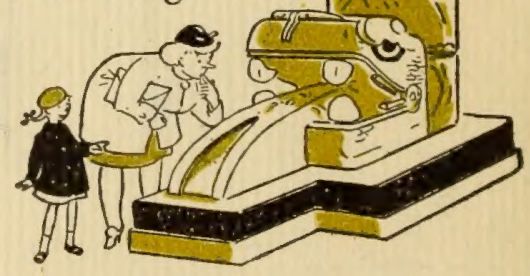
6 
society is primarily the result of the needs and desires of the community. To get down to particulars, this Museum-The American Museum of Natural History-is the great and celebrated institution it has become because the public wants just such a museum as this. They like what we have done here and they applaud it. The measure of their interest is the ever-increasing numbers that frequent our halls. We could, of course, revert to the old-fashioned, stuffy museum of unhallowed memory-the kind that people used to think of when museums were mentionedwhere serried rows of unrelieved specimens faced bored and infrequent visitors with impregnable barriers to knowledge. But no one would want it. Having experienced the beauty and excitement of intimate contact with knowledge, having learned to look to the museum for guidance in understanding the world in which we live, it is inconceivable that the public would permit the museum to relinquish its necessary role in the community.

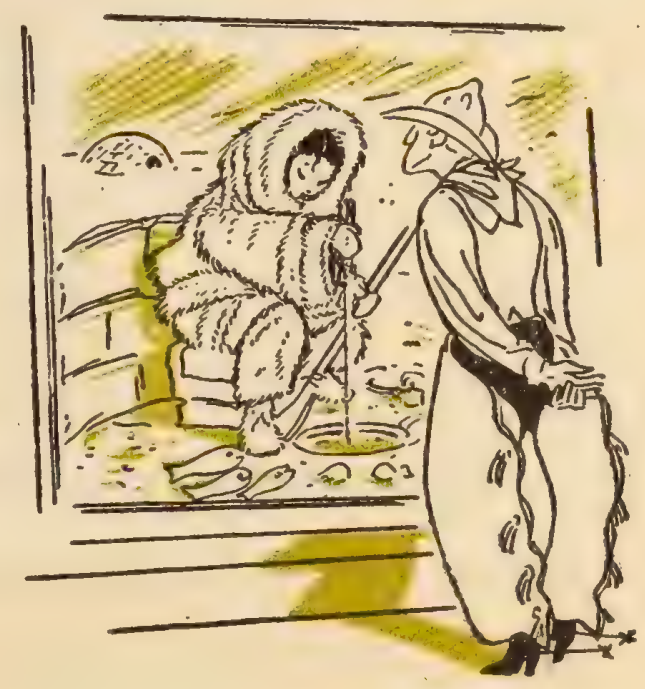




\section{At no time in our past has the}

place of a progressive, modern museum been more vital. There are two reasons for this expanding function of the museum. One is the deep seated desire of our people for knowledge. When given

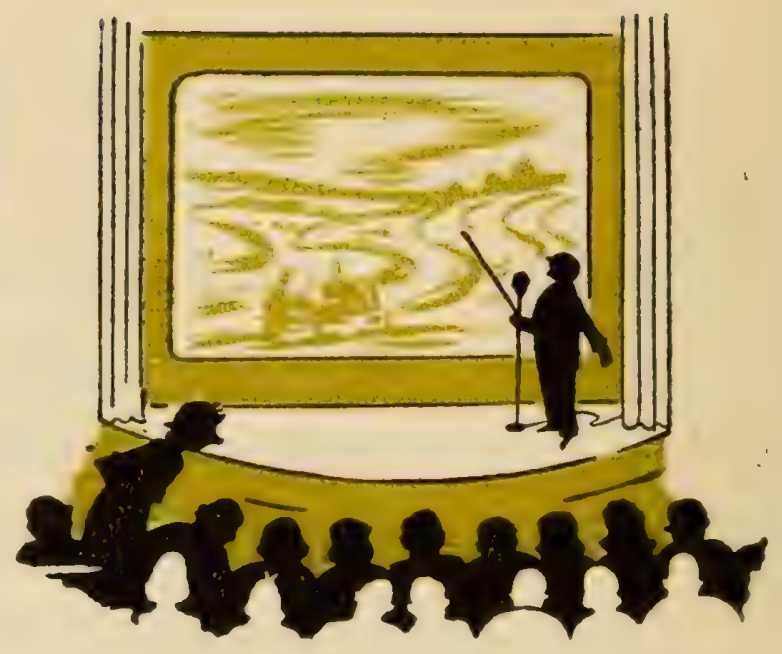
the opportunity, they seize it avidly. Here in the museum whole areas of science, and enchanting vistas of understanding, are opened up to countless people for the first time. And even those who have some background of special learning, find in our exhibits new appreciation and refreshment. Those of us who are depressed by the spectacle of thousands storming the theatres for a sight of a popular crooner, may renew their faith in the public taste by witnessing our crowded halls on week-ends and holidays.

The second reason for the increasing significance of the museum in the life of the community lies in its role as the intelligent citizen's guide in the world at large. For this world of increasing complexity 8 
where our power for good as well as for evil is expanding, no citizenry can neglect its obligation to understand the basic principles that govern man and nature. No public can effectively survive in a 20 th century world with an 18th century mental equipment. The whole background of the modern world must be made accessible. This can come about only through education and by the translation of the best knowledge to the public. The necessity is no less when we turn to our own country. The United States has moved beyond its pioneering days when waste

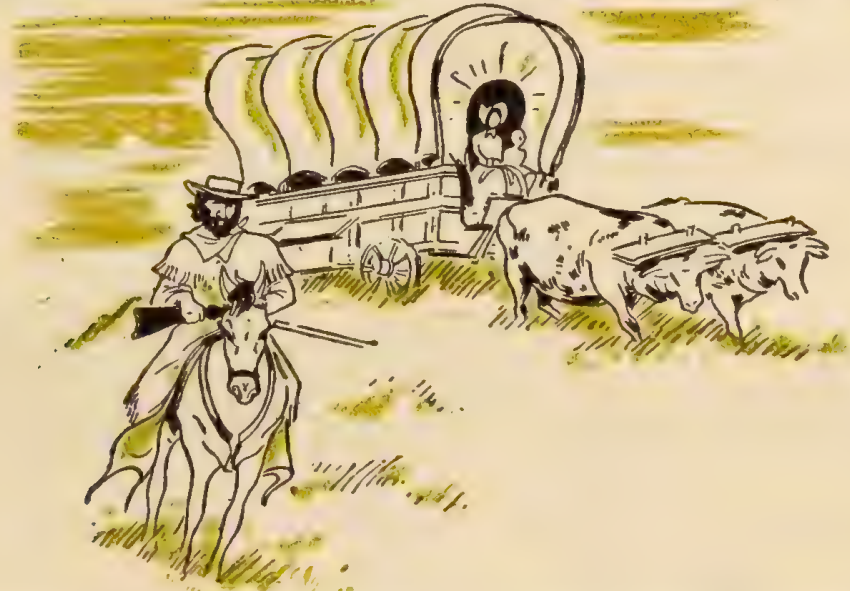

and destruction of its natural resources were possible because our abundance was so great and apparently inexhaustible. The time has come when we must learn how to preserve our heritage and maintain its fertility in order to survive in a world of growing pressures and closer competition. 
Not only must we teach our people these lessons and demonstrate the best knowledge we have, but we must educate them to appreciate the role of man in nature and the effects on mankind of a changing world.

Let us not suppose that these things will be taken care of for us automatically by any government seated in Washington. In a democ. racy the public must be informed and must appreciate the common weal in order that appropriate action be taken in good time and with the complete support of the people. It would be instructive, for example, to know how many millions of dollars worth of national assets are now being lost annually for the lack of a modest fraction spent in public education on the subject of conservation.

Recognizing its obligations to the post war community and eager to contribute its share in creating the attitudes and understanding es. sential for the national welfare, this Museum has envisaged an ambitious and well-rounded program of education and research in line with its responsibilities. It will seek to bring to the public the knowledge essential to a comprehension of our world in a manner calculated to attract attention. It will direct its efforts to display sound principles of 10 
science with the conviction that a public familiar with the facts of life as they are is necessary in a democracy functioning in its best sense.

No contribution that the museum can make in its exhibits is more likely to contribute solidly and effectively to such a program than its project for a series of halls dealing with man and mankind. Aside from the natural interest we all share in man as a biological and as a social organism, the problems relating to mankind have a special urgency now and in the immediate future. Men of diverse cultures and ethnic origins must learn to get along with each other and to cooperate for the benefit of all mankind or we shall continue to have war and chaos. How can our men of good will and vision work for peace and understanding if the people themselves are locked behind parochial walls of suspicion and dislike for anything and anyone outside the familiar limits?

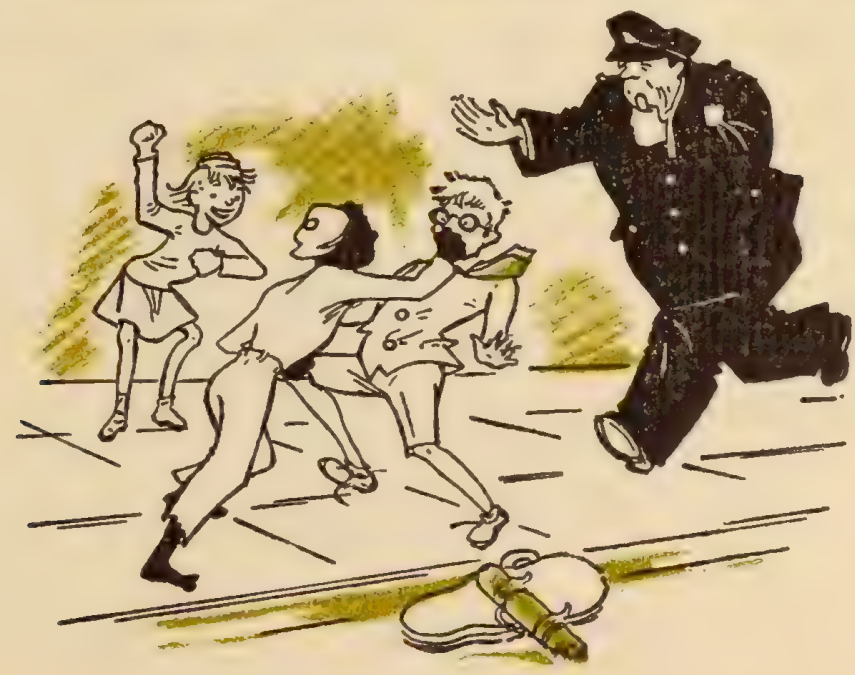


How can the people understand their own place in the world if they have no point from which to see it? What better place can they have in which to learn about their neighbors from Persia to Peru than in the museum where the cultures of all mankind are displayed and where appreciation for the achievements of others may be taught? Who can measure the imaginative insight into the soul of a foreign people that a

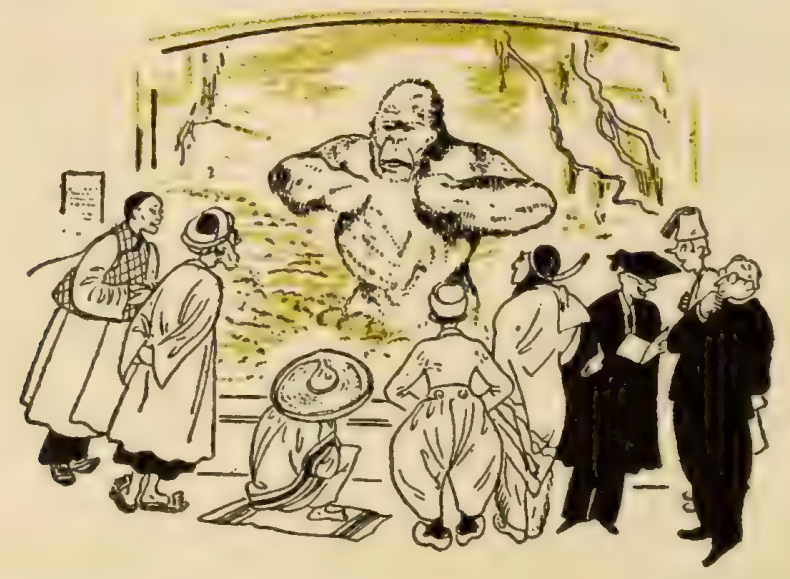

piece of stone sculpture, an ivory carving or a simple tool may inspire in the mind of a visitor to our halls? And if these fragments from distant cultures be enlivened by exhibits designed to give an understanding of their origin, their history and the relation to their environment, they become potent agents in building a bridge of respect and tolerance between peoples separated by the unfamiliar and the strange. 
Not only must we learn to know the various peoples of the world so that we may work with them, we must also acquire a deeper comprehension of our own country - the people who comprise it and the land that supports them. In a small homogeneous country, it is possible for the resident of one district to understand the problems and history of another since they are apt to be similar, if not identical, with his own. But in a country such as ours with its continental diversities of climate, soil and topography and with its variegated strains of population, the Vermonter and the New Mexican, for example, might have some difficulty in meeting on a common ground of experience. It is easy to see how an Iowa farmer, conditioned by the fertile plains of his state, might lack an appreciation of the plight of the tenant farmer of the South.

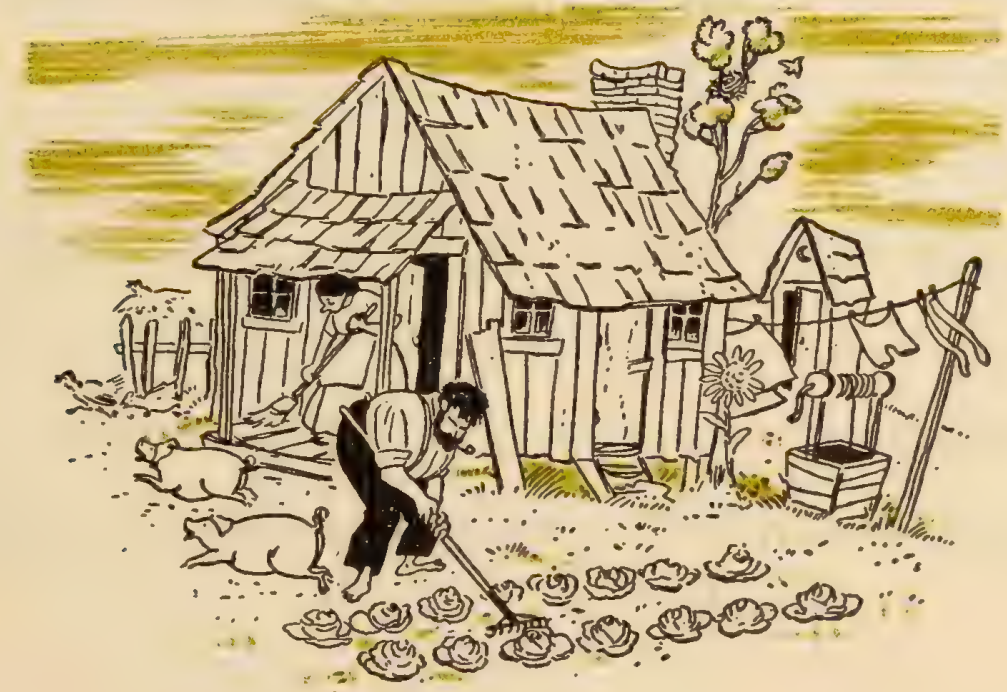


The lines of cleavage and interest that can divide our people occur in other spheres as well. To mention one, our industrial and ur.

banized population knows little of the agricultural complexities that face a large part of the remainder of the country. The fact is that as a nation we have gradually become highly differentiated into a number of more or less distinct groups motivated by group interests and indifferent or hostile to the claims of others. Because we have become accustomed to these lines of division, it would be dangerous to assume that they are unimportant. We have fought one war in our history on an issue that involved group interest although fifty years before the actual outbreak of hostilities such an eventuality would have seemed fantastic to the ordinary American. But not all internal stresses come to a head in war. Most of them fester and corrupt the body of the nation.

\section{What has the museum to do with all these national difficulties, in-} justices and cleavages? The answer is-a great deal as a scientific institution dispensing knowledge sorely needed and for the most part unobtainable by the ordinary citizen. We cannot, of course, and would not attempt to enter into all the ramifications suggested above. We can, 14 
however, teach our public the truth about their country and the people who make up its population. We can lead the city dweller into the green pastures of his fellow American farmer. We can show the richness of our origins, the epic of our national progress, the inadequacies of our utilization of our cultural and ecological resources and the biological trends

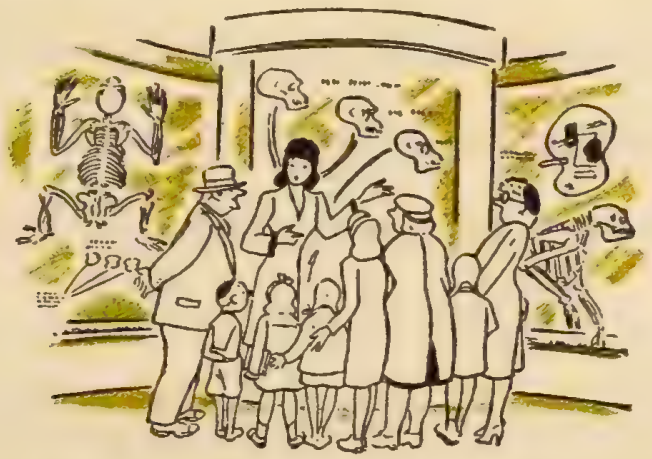

of our population. We can teach by these means an understanding of the country as a whole, transcending and compensating the limited experience of special groups. We must do this or pay a high price indeed for our specialized living.

To do the job thus briefly outlined requires two essentials: an agency and financial support. The American Museum of Natural History is the agency. It enjoys a long tradition of public service. As an educational institution, backed by the highest scientific repute, it claims 
the attention of the entire country. Its public includes every class and every age. The serious student eager to complete his education comes to the Museum. Visitors from foreign lands and from every corner of the United States come to its halls as one of the principal visits to be made in New York. Thousands upon thousands read its publications. For the general public the Museum stands at the frontiers of knowledge. Such an institution is an invigorating influence in the life of the nation. It can and does claim the trust and respect of its visitors because its reputation for objective truth is unassailable. Its very merit rests upon that integrity.

But such an agency, no matter how noble its tradition or ex. alted its purpose, cannot continue its service on the level it deserves without substantial support. For a long time, now, the Museum has approached its benefactors with some hesitancy and reluctance. Depressions and wars have stressed the urgency of other immediate claims. Now our needs can no longer be neglected. They, too, are immediate and pressing. Although the Museum cannot measure its service by the number of lives saved or hospital beds provided, its purpose in terms of the national welfare is no less vital. 


\section{Abraham Lincoln said 'Public sentiment is everything. With}

public sentiment nothing can fail; without it, nothing can succeed."?

If public sentiment is based upon an enlightened knowledge of Man and his environment we may face the future unafraid. But the shackles of ignorance, prejudice, and like causes of human error and conflict must be broken. In the process, the Museum has a great and important part to play. Granted adequate support, the Museum will meet its obligations to the community.

H. L. S.

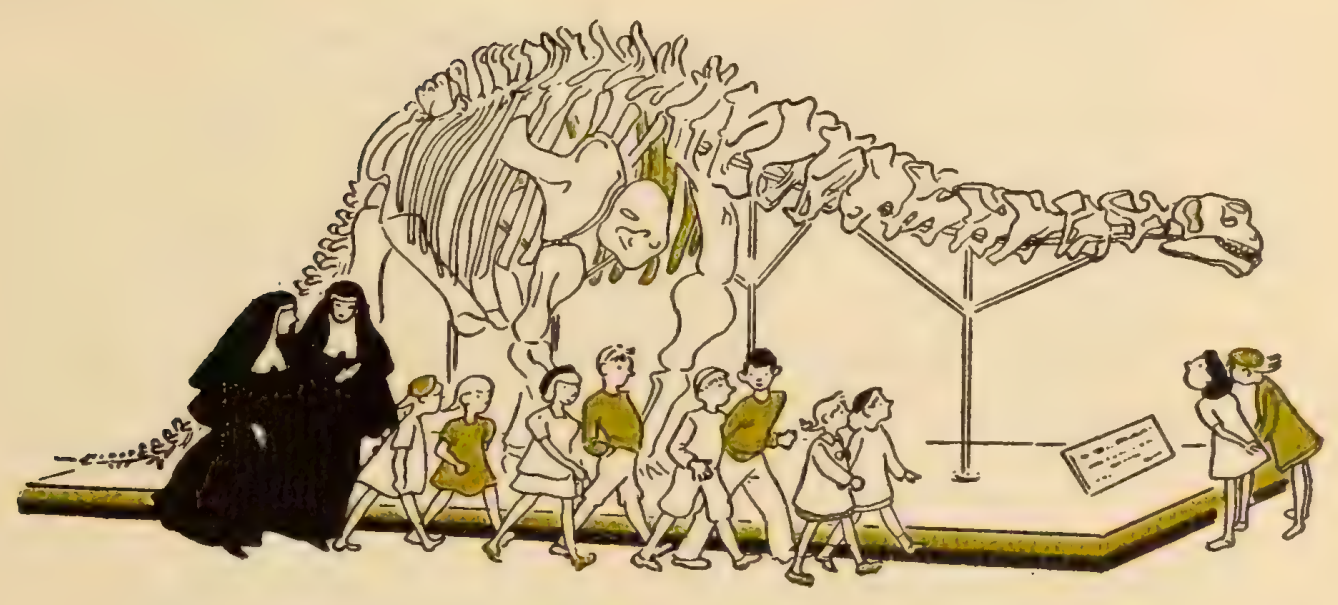


Although the City of New York provides in part for museum maintenance, approximately seventy per cent of the total income of the Museum is derived from private support including income from endowments, memberships and annual contributions. $A$ great part of such income is non-recurrent. The Museum is in constant need of additional funds, new members and contributors. In order to carry out plans for education, research and the modernization of exhibits and buildings, an additional ten million dollars is required.

Gifts are exempt from Federal and State Income Taxes up to fifteen per cent of income and may be made in the following ways: (1) For General Purposes; (2) Endowment; and (3) Special Purposes. 


\section{OFFICERS AND TRUSTEES}

F. TRUBEE DAVISON

President

CLEVELAND E. DODGE Second Vice-President

MALCOLM P. ALDRICH

JAMES ROWLAND ANGELL

ANDREY AVINOFF

HARRY PAYNE BINGHAM

ROBERT WOODS BLISS

W. DOUGLAS BURDEN

HAROLD BENJAMIN CLARK

S. SLOAN COLT

C. SUTDAM CUTTING

LINCOLN ELLSWORTH

CHIIDS FRICK

CHAUNCEY J. HAMLIN

ARCHER M. HUNTINGTON

\section{ALBERT EIDE PARR}

Director

HAROLD E. ANTHONY Mammals

FRANK A. BEACH Animal Behavior

CHARLES M. BOGERT Amphibians and Reptiles

C. M. BREDER, JR.

Fishes and Aquatic Biology

BROOKS F. ELLIS

Micropaleontology

\author{
E. ROLAND HARRIMAN \\ Treasurer
}

MICHAEL LERNER

ROBERT EARLL MCCONNELL

FRANK R. MCCOY

RICHARD K. MELLON

JUNIUS S. MORGAN

FREDERICK H. OSBORN

DANIEL E. POMEROY

WILLIAM PROCTER

A. HAMILTON RICE

BEVERLEY R. ROBINSON

JOHN D. ROCKEFELLER, 3RD

DEAN SAGE

KEITH SPALDING

\section{SCIENTIFIC STAFF}

\section{Chairmen of Departments}

$$
\begin{array}{r}
\text { JOHN ERIC HIL, } \\
\text { Acting }
\end{array}
$$

Comparative Anatomy

$$
\begin{aligned}
& \text { MARIAN LOCK WOOD, } \\
& \text { Acting } \\
& \text { Astronomy and } \\
& \text { Hayden Planetarium }
\end{aligned}
$$
ROBERT CUSHMAN MURPHY
Birds

\section{WAYNE M. FAUNCE \\ Vice-Director$$
\text { Vice-Director }
$$

\author{
A. PERRY OSBORN \\ First Vice.President \\ CLARENCE L. HAY \\ Secretary
}

LEONARD C. SANFORD

ARTHUR S. VERNAY

FREDERICK M. WARBURG

CORNELIUS V. WHITNEY

Ex-Officio Trustees

FIORELLA H. LA GUARDIA

Mayor

ROBERT MOSES

Commissioner of Parks

JOSEPH D. MCGOLDRICK

Comptroller

\section{CHARLES RUSSELL Education}
HERBERT F. SCHWARZ, Insects and Spiders Acting

H. L. SHAPIRO Anthropology

GEORGE GAYLORD SIMPSON Geology and Paleontology

\section{Museum Contributors Program}

A. PERRY OSBORN, Chairman

MRS. WINTHROP W. ALDRICH, Vice-Chairman
E. ROLAND HARRIMAN, Treasurer

DORATHEA M. SIEGLE, Executive Assistant 


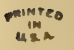





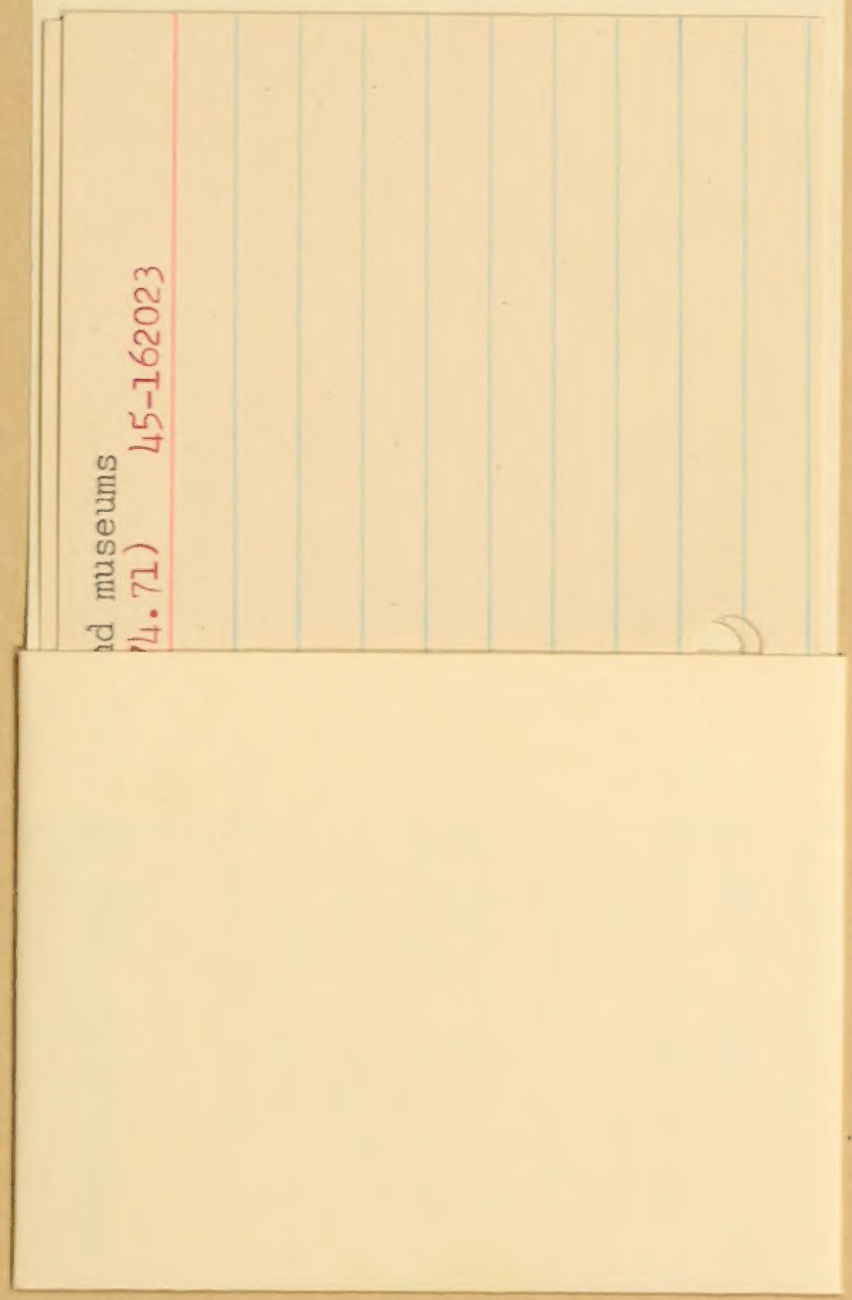


100057412 